Session 8-1

\title{
A Review of Accredited Multidisciplinary Engineering Programs and ASEE'S Role as the Lead Society for Their ABET Accreditation
}

\author{
James B. Farison, Zhuocheng Yang \\ Department of Electrical and Computer Engineering \\ Baylor University
}

\begin{abstract}
As the result of the ABET Board of Directors action in spring 2005, ASEE is now the lead society for the accreditation evaluation of multidisciplinary engineering programs, effective with the accreditation visits that began in the fall of 2006. In this context, the terminology "multidisciplinary engineering programs" is defined as the set of engineering programs with one of the following program titles (and a few slight variations): Engineering (including General Engineering), Engineering Physics, and Engineering Science(s). An important characteristic that these programs have in common is that they do not have "program criteria" that supplement the "general criteria" that apply to the accreditation criteria for all other engineering programs. This new role for ASEE means, among other things, that ASEE now has membership on the ABET Engineering Accreditation Commission (EAC) and is responsible for recruiting and recommending Program Evaluators (PEVs) to ABET for accreditation visits for multidisciplinary engineering programs. This paper presents information about the 72 multidisciplinary engineering programs at 69 institutions that are currently assigned to ASEE for their ABET accreditation review, as well as information about the initial period of ASEE's new role and some perspective from the initial two years of actual visits and other information about the near future.
\end{abstract}

\section{Introduction}

One of the significant distinctions of a substantial number of baccalaureate engineering programs is that they intentionally do not align naturally with a currently so-called "traditional discipline" (such as civil engineering, electrical engineering, mechanical engineering, etc.). Such programs have been called "non-traditional" or, more recently, "multidisciplinary" engineering programs. In the context of this paper, they include programs called engineering, general engineering, engineering science, engineering physics, and a few other similar (non-disciplinary) program titles. At this writing, there are 72 accredited engineering programs at 69 institutions that are classified by ABET in this "multidisciplinary" category.

Extensive information about some of the typical characteristics of multidisciplinary engineering programs is available elsewhere. ${ }^{1,2,3}$ For example, one study ${ }^{2}$ suggested a classification of engineering (including general engineering) and engineering science programs that sought to identify and distinguish the institutional purposes for these programs as one of three purposes: "philosophical," "flexible," or "instrumental." One thing these programs clearly were not was "disciplinary," as used here. 


\section{Multidisciplinary Engineering Programs}

The ABET website ${ }^{4}$ currently lists accredited engineering programs under a set of drop-down menu titles, one of which is "Engineering, Engineering Physics \& Engineering Science." That list currently comprises programs with one of those three titles, plus General Engineering and a small number of other titles that ABET has classified as multidisciplinary (i.e., with program names that are judged not to be "disciplinary" names). The current roster assigned to ASEE for program accreditation under that heading includes 69 institutions offering 72 accredited programs. These numbers are likely to change annually as any institution may not seek reaccreditation of a presently listed program or may in fact terminate the program and, on the other side, institutions may present new programs for accreditation upon graduation of their first students(s) or anytime thereafter.

In this multidisciplinary engineering program analysis, the following five groups of accredited multidisciplinary engineering programs are identified from the current ABET website listing. There are 34 Engineering programs. Two programs with the title General Engineering and one with Engineering (General) are cited here as General Engineering. There are 11 programs with the title Engineering Science or Engineering Sciences. There are 19 programs labeled Engineering Physics (including one labeled as Physics - Engineering Physics option). Five programs included in this ABET listing and grouped below as Other Multidisciplinary Engineering programs have the names of Engineering and Applied Science, Engineering and Public Policy, Fluid and Thermal Engineering Science, Integrated Engineering, and a variation on Mechanical Engineering. In summary, the subsequent information in this paper relates to the following programs:

$\begin{aligned} & 34 \text { Engineering programs } \\ & 3 \text { General Engineering programs } \\ & 11 \text { Engineering Science(s) programs } \\ & 19 \text { Engineering Physics programs } \\ & \frac{5}{72} \text { Other Multidisciplinary Engineering programs } \\ & \text { Multidisciplinary engineering programs }\end{aligned}$

Since three institutions have two different multidisciplinary engineering programs, there are 69 different institutions with these 72 currently accredited multidisciplinary engineering programs. And, subject to change by ABET, these 72 programs are currently under the purview of ASEE accreditation review responsibility.

Further information about the 69 institutions and 72 programs is provided by the Tables in the appendix following this text. The data for those tables, which include only those institutions with one or more of the types of currently-accredited multidisciplinary engineering programs listed here, are from the ABET website ${ }^{4}$ at the time of this writing. The alphabetical ordering of institutions used here is the same as that used by ABET. The official assignment of program accreditation roles is the responsibility of ABET, and may differ from the information presented here. Because of the importance of the subject of program accreditation, the authors have taken 
special care to be both precise and correct, hereby apologize in the event of any errors, and welcome the corrections of any inaccurate or incomplete information.

Table 1 displays the year of first accreditation for the 72 currently accredited multidisciplinary engineering programs. This and the following Tables and statistics include only those institutions and programs that are accredited now. The current accreditation record began in 1936, the first year that national professional accreditation was offered. The list of currently accredited programs includes four institutions that were first accredited in that initial year. At that time, accreditation was under the Engineers Council for Professional Development (ECPD), the forerunner to the current ABET. The next 2 newly accredited multidisciplinary engineering programs were recognized in 1949 (13 years later). There are 2 more currently accredited programs that were first accredited in the decade of the 1950's, 8 in the 1960's, 9 in the 1970's, 12 in the 1980 's, 17 in the 1990 's, and already 18 in the 2000 's.

Table 2 provides, alphabetically based on the form of the institution name used by ABET, a list of the accredited multidisciplinary engineering programs currently offered, showing:

the names of the institutions,

the accredited multidisciplinary engineering programs offered,

the years of their first accreditation,

the numbers of other accredited engineering programs offered, and

the years of the next general accreditation review.

In 33 of these 69 institutions, the multidisciplinary engineering programs are the only ABETaccredited engineering programs offered, while 26 of these 69 institutions offer 4 or more additional accredited engineering programs.

\section{ASEE's Accreditation Role}

A unique characteristic of these multidisciplinary engineering programs is that they do not have the additional "program criteria" for accreditation that most other "traditional" engineering programs do. Indeed, the novelty, variety, and interdisciplinary nature of these "multidisciplinary" programs would not easily accommodate the type of additional program criteria that the traditional programs have. That distinction was at the root of an ASEE member initiative that can be traced back at least to late 2001. It was believed by some involved with multidisciplinary engineering programs that there was a potential bias, possibly unintended or even subconscious, built into the accreditation of these programs through the program evaluation process. The majority of the program evaluators were likely themselves specialists through the doctoral level in a traditional disciplinary field. Many of them were teaching in a traditional disciplinary engineering educational program. Further, the PEV training provided to them by the disciplinary organizations (ASCE, IEEE, ASME, etc.) was also often led by doctoral specialists from that field and for which the disciplinary program had "program criteria." All program evaluators, including those for multidisciplinary engineering programs, came through that process. It was felt that this combination presented too strong a tendency to lead to a bias, even if consciously unintended, that every program should have a focus of disciplinary depth closely aligned to one of the recognized and well established fields of engineering. From that perspective and in contemporary ABET accreditation terminology, this issue may not have been 
an accreditation process Deficiency, perhaps not even a Weakness, but it certainly was at least a strong Concern.

Several references describe the history ${ }^{5,6}$ and process $^{7}$ through which ASEE has become involved with multidisciplinary engineering program accreditation for ABET. In a Prism article ${ }^{8}$ while she was ASEE President, Sherra E. Kerns noted that "ASEE is a founding member society of ABET." Finally, in 2005, after several years of groundwork, from the initiative of ASEE members, the support of many other multidisciplinary engineering educators, and the cooperation of both ASEE and ABET leadership, ASEE had become the lead society for the accreditation of multidisciplinary engineering (and engineering technology) programs.

As a result of this new accreditation role and with leadership from Edwin C. Jones, Jr. and the support of many other ASEE leaders, ASEE adapted and strengthened its Accreditation Activities Committee (AAC) during 2005-06 to include this new role in its purview, in preparation for the 2006-07 accreditation cycle. ${ }^{9}$ With ASEE's new role in the accreditation of multidisciplinary engineering programs, the schedule of the accreditation cycle and its accompanying need for program evaluators and related responsibilities became of immediate importance for the recruiting, training and assigning of that initial set of evaluators. The primary AAC meeting occurs at the ASEE Annual Conference each year. The current membership of AAC is listed on-line. ${ }^{10}$ Information about applying to become an ASEE program evaluator for multidisciplinary engineering programs is given at the ASEE website. ${ }^{11}$

\section{Accreditation of the Multidisciplinary Engineering Programs}

The roster of accredited multidisciplinary engineering programs and the number of ASEE program evaluators needed changes each accreditation cycle, as illustrated in two earlier papers. ${ }^{12,13}$ Based on the current listing from the ABET website ${ }^{4}$ as compiled in Table 2, Table 3 gives the number of institutions and the numbers of multidisciplinary engineering program accreditation visits implied for the six-year accreditation cycle from 2007-08 through 2012-13. Clearly, there is a wide variation reflected by those data in the workload from year to year, ranging from five programs at five institutions in 2008-09 to 20 programs at 20 institutions in 2011-12. In addition to the numbers of visits over that six-year cycle indicated in Table 3 , Table 4 lists the specific institutions reflected in the data of Table 3. However, there are other factors that significantly influence the number of visits and number of visitors needed that are not reflected in either of those two tables. For example, each visit requires the minimum of the team chair and an evaluator for each program being reviewed but, in the case of a visit for an institution with a single program review, two evaluators are required. In this case, the two evaluators share the assignment responsibility and combine their assessments into a single accreditation draft report. Even more elusive are those variables that cannot be identified numerically until ABET completes its visit assignments to each of the many PEV-sending organizations during the summer before the fall visits begin.

The information available in March 2008 does give an initial indication of the anticipated ASEE program evaluator workload for fall 2008 assignments (and, indeed, for the next several years), but there are several other variables that impact significantly the actual number of visitors required any specific year. These include new programs seeking accreditation, currently 
accredited programs that no longer seek accreditation, any of the several types of interim visits, and any other "innovations and special assignments" by ABET as they seek to fulfill their overall accreditation responsibilities. Therefore, the actual number of visitors needed each year remains uncertain until the roster of program accreditation assignments is finalized by ABET a few months preceding the visit schedule. In order to develop some indication of the likely variations of PEV workload from year to year, the chart below tabulates ASEE's actual experiences for the initial two years of accreditation responsibility. Preceding the actual ABET report of ASEE PEV visit assignment responsibility each year, only the first three entries are available from the ABET website. Nonetheless, this record should be helpful in ASEE planning for future years.

\begin{tabular}{|c|c|c|}
\hline Source of ASEE PEV Assignments Needed & $\begin{array}{l}\text { Fall } 2006 \\
\text { Experience }\end{array}$ & $\begin{array}{l}\text { Fall } 2007 \\
\text { Experience }\end{array}$ \\
\hline $\begin{array}{l}\text { Institutions with a program requiring an ASEE PEV } \\
\text { listed for accreditation visits on ABET website }\end{array}$ & 13 & 12 \\
\hline $\begin{array}{l}\text { Institutions with multiple ASEE programs requiring } \\
\text { another ASEE PEV }\end{array}$ & +1 & \\
\hline $\begin{array}{l}\text { Institutions with a single accredited program (each } \\
\text { requiring an additional ASEE PEV) }\end{array}$ & +2 & +3 \\
\hline $\begin{array}{l}\text { Institutions requesting an initial accreditation visit } \\
\text { requiring an ASEE PEV }\end{array}$ & +3 & +1 \\
\hline $\begin{array}{l}\text { Institutions requesting an initial accreditation visit } \\
\text { with a single program (requiring second ASEE PEV) }\end{array}$ & & +1 \\
\hline $\begin{array}{l}\text { Institutions not seeking a visit for an accredited } \\
\text { program (that would have required an ASEE PEV) }\end{array}$ & -1 & -2 \\
\hline $\begin{array}{l}\text { Institutions with a program having an interim visit } \\
\text { requiring an ASEE PEV }\end{array}$ & +1 & +3 \\
\hline $\begin{array}{l}\text { Institutions with a program having an interim visit } \\
\text { requiring an additional ASEE PEV }\end{array}$ & & +1 \\
\hline $\begin{array}{l}\text { Institutions not on the ABET website but added later } \\
\text { by ABET (e.g., international institution) }\end{array}$ & & +1 \\
\hline $\begin{array}{l}\text { ABET request for an ASEE PEV for a program not } \\
\text { normally an ASEE PEV assignment }\end{array}$ & & +1 \\
\hline Website number of ASEE PEVs & 16 & 15 \\
\hline Final number of institutions with ASEE PEVs & 16 & 16 \\
\hline Final number of programs for ASEE PEVs & 17 & 16 \\
\hline Final number of ASEE PEVs & 19 & 21 \\
\hline
\end{tabular}

\section{Summary}

The background and additional responsibilities related to a significant new ASEE initiative have been reviewed, together with a focus on the institutions and their multidisciplinary engineering programs for which ASEE is now the lead society in the ABET engineering accreditation process. Further, based on the first two years of experience, the process of estimating the number of ASEE's program evaluators required for ABET accreditation visits has been reviewed and illustrated for those first two years of ASEE experience. 
TABLE 1. Year of First Accreditation of Multidisciplinary Engineering Programs

\begin{tabular}{|c|c|c|c|c|c|}
\hline $\begin{array}{c}\text { Year of } \\
\text { Accreditation }\end{array}$ & Engineering & $\begin{array}{c}\text { General } \\
\text { Engineering }\end{array}$ & $\begin{array}{c}\text { Engineering } \\
\text { Science }\end{array}$ & $\begin{array}{c}\text { Engineering } \\
\text { Physics }\end{array}$ & $\begin{array}{c}\text { Other } \\
\text { Multidisc. } \\
\text { Engineering }\end{array}$ \\
\hline 1936 & 3 & 1 & - & - & - \\
\hline 1949 & - & - & - & 2 & - \\
\hline 1953 & - & - & - & 1 & - \\
\hline 1959 & - & - & 1 & - & - \\
\hline 1962 & 1 & - & 1 & - & - \\
\hline 1964 & - & - & - & - & 1 \\
\hline 1965 & - & - & 2 & 1 & - \\
\hline 1969 & - & - & 2 & - & - \\
\hline 1971 & 1 & - & 1 & 1 & 1 \\
\hline 1972 & - & - & - & 1 & - \\
\hline 1975 & 1 & - & - & - & - \\
\hline 1976 & 1 & - & - & - & - \\
\hline 1977 & 1 & - & - & 1 & - \\
\hline 1981 & 1 & 1 & - & - & - \\
\hline 1983 & 1 & - & - & - & - \\
\hline 1985 & 1 & - & 1 & - & - \\
\hline 1986 & - & - & - & 1 & - \\
\hline 1987 & 2 & - & - & - & - \\
\hline 1988 & 1 & - & - & 1 & - \\
\hline 1989 & 1 & - & - & - & 1 \\
\hline 1990 & 2 & - & - & - & - \\
\hline 1991 & 1 & - & 1 & - & - \\
\hline 1993 & - & - & - & 2 & - \\
\hline 1994 & 3 & - & - & 1 & - \\
\hline 1995 & 1 & - & 1 & - & - \\
\hline 1997 & 2 & - & - & - & - \\
\hline 1998 & - & - & - & 1 & - \\
\hline 1999 & 1 & 1 & - & - & - \\
\hline 2000 & 3 & - & - & - & - \\
\hline 2001 & - & - & - & 2 & - \\
\hline 2002 & 1 & - & - & - & 1 \\
\hline 2004 & 1 & - & - & 1 & - \\
\hline 2005 & 1 & - & 1 & - & 1 \\
\hline 2006 & 1 & - & - & 1 & - \\
\hline 2007 & 2 & - & - & 2 & - \\
\hline Total & 34 & 3 & 11 & 19 & 5 \\
\hline
\end{tabular}

Proceedings of the 2008 ASEE Gulf-Southwest Annual Conference

The University of New Mexico - Albuquerque

Copyright $(0) 2008$, American society for Engineering Education 
TABLE 2. Multidisciplinary and Other Engineering Programs

\begin{tabular}{|c|c|c|c|c|c|c|c|c|}
\hline \multirow[b]{2}{*}{ College / University } & \multicolumn{5}{|c|}{ Multidisciplinary Engineering Areas } & \multicolumn{3}{|c|}{ Other Information } \\
\hline & 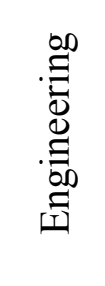 & 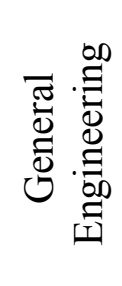 & 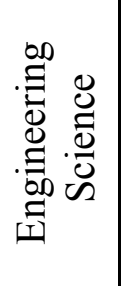 & 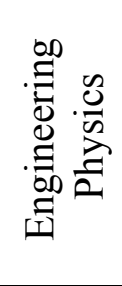 & 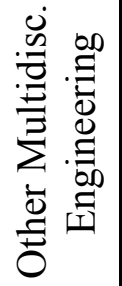 & 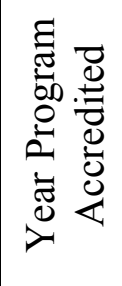 & 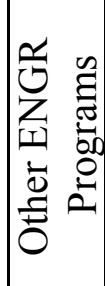 & 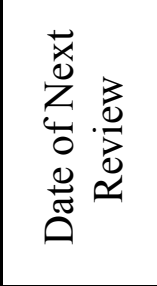 \\
\hline Irkansas State University & $\sqrt{ }$ & & & & & 1987 & 0 & $2010-11$ \\
\hline Baylor University & $\sqrt{ }$ & & & & & 1989 & 2 & $2012-13$ \\
\hline $\begin{array}{l}\text { alifornia Institute of } \\
\text { echnology }\end{array}$ & & & & & $\sqrt{ }$ & 1964 & 3 & 2011-12 \\
\hline Calvin College & $\sqrt{ }$ & & & & & 1987 & 0 & $2007-08$ \\
\hline \begin{tabular}{|l|} 
Jarnegie Mellon University \\
\end{tabular} & & & & & $\sqrt{ }$ & 1989 & 5 & $2012-12$ \\
\hline $\begin{array}{l}\text { Case Western Reserve } \\
\text { University }\end{array}$ & & & & $\sqrt{ }$ & $\sqrt{ }$ & \begin{tabular}{|c|}
$2007 \mid$ \\
1971
\end{tabular} & 10 & $2012-13$ \\
\hline 'olorado School of Mines & $\sqrt{ }$ & & & $\sqrt{ }$ & & \begin{tabular}{|c|}
1983 \\
1977
\end{tabular} & 6 & $2012-12$ \\
\hline Colorado State University & & & $\sqrt{ }$ & & & 1969 & 7 & $2007-08$ \\
\hline \begin{tabular}{|l|} 
artmouth College \\
\end{tabular} & $\sqrt{ }$ & & & & & 1936 & 0 & $2009-1 C$ \\
\hline University of Denver & & $\sqrt{ }$ & & & & 1999 & 3 & $2010-11$ \\
\hline \begin{tabular}{|l|} 
)ordt College \\
\end{tabular} & $\sqrt{ }$ & & & & & 1991 & 0 & $2011-12$ \\
\hline $\begin{array}{l}\text { Embry-Riddle Aeronautical } \\
\text { University - Daytona Beach }\end{array}$ & & & & $\sqrt{ }$ & & 1993 & 4 & $2007-08$ \\
\hline Jniversity of Florida & & & $\sqrt{ }$ & & & 1965 & $12 *:$ & $2012-12$ \\
\hline Fort Lewis College & & & & $\sqrt{ }$ & & 2004 & 0 & $2009-10$ \\
\hline \begin{tabular}{|l} 
Jeneva College \\
\end{tabular} & $\sqrt{ }$ & & & & & 1995 & 0 & $2012-12$ \\
\hline George Fox University & $\sqrt{ }$ & & & & & 2005 & 0 & $2010-11$ \\
\hline Irand Valley State University & $\sqrt{ }$ & & & & & 1990 & 3 & $2010-11$ \\
\hline $\begin{array}{l}\text { Harvard University } \\
\text { (Cambridge, MA) }\end{array}$ & & & $\sqrt{ }$ & & & 1962 & 0 & $2009-10$ \\
\hline Iarvey Mudd College & $\sqrt{ }$ & & & & & 1962 & 0 & $2009-1 C$ \\
\hline Hofstra University & & & $\sqrt{ }$ & & & 1971 & 2 & 2011-12 \\
\hline Iope College & $\sqrt{ }$ & & & & & 2000 & 0 & $2011-12$ \\
\hline Idaho State University & $\sqrt{ }$ & & & & & 1985 & 3 & $2011-12$ \\
\hline Jniversity of Illinois at U-C & & $\sqrt{ }$ & & & & 1936 & 11 & $2007-0 \varepsilon$ \\
\hline
\end{tabular}

** Programs offered by the same institution at multiple campuses counted as one program. 
TABLE 2 (Continued). Multidisciplinary and Other Engineering Programs

\begin{tabular}{|c|c|c|c|c|c|c|c|c|}
\hline \multirow[b]{2}{*}{ College / University } & \multicolumn{5}{|c|}{ Multidisciplinary Engineering Areas } & \multicolumn{3}{|c|}{ Other Information } \\
\hline & 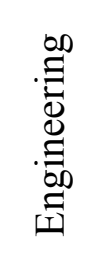 & 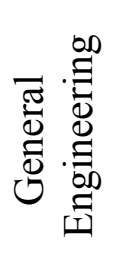 & 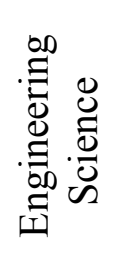 & 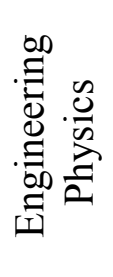 & 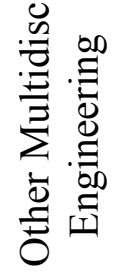 & 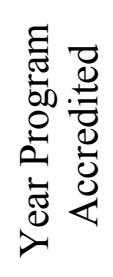 & 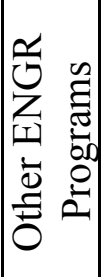 & 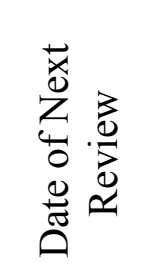 \\
\hline ohn Brown University & $\sqrt{ }$ & & & & & 1997 & 0 & 2008-0s \\
\hline The University of Kansas & & & & $\sqrt{ }$ & & 1949 & 8 & $2012-13$ \\
\hline .eTourneau University & $\sqrt{ }$ & & & & & 1988 & 0 & 2008-0 \\
\hline Loyola College in Maryland & & & $\sqrt{ }$ & & & 1991 & 0 & 2011-12 \\
\hline Jniversity of Maine & & & & $\sqrt{ }$ & & 1949 & 8 & 2012-1: \\
\hline $\begin{array}{l}\text { University of Maryland } \\
\text { College Park }\end{array}$ & $\sqrt{ }$ & & & & & 1976 & $9 * *$ & 2011-12 \\
\hline $\begin{array}{l}\text { Massachusetts Institute of } \\
\text { "echnology }\end{array}$ & $\sqrt{ }$ & & & & $\sqrt{ }$ & $\begin{array}{c}2002 \\
2002\end{array}$ & 12 & 2007-0ع \\
\hline AcNeese State University & $\sqrt{ }$ & & & & & $\begin{array}{c}1981 . \\
1988 \\
1989\end{array}$ & 0 & 2009-1c \\
\hline Mercer University & $\sqrt{ }$ & & & & & 1990 & 0 & $2007-0 \varepsilon$ \\
\hline Messiah College & $\sqrt{ }$ & & & & & 1994 & 0 & 2011-12 \\
\hline $\begin{array}{l}\text { Aichigan Technological } \\
\text { Jniversity }\end{array}$ & $\sqrt{ }$ & & & & & 1975 & 9 & 2010-11 \\
\hline $\begin{array}{l}\text { Iontana Tech of the } \\
\text { Iniversity of Montana }\end{array}$ & & $\sqrt{ }$ & & & & 1981 & 6 & 2010-11 \\
\hline \urray State University & & & & $\sqrt{ }$ & & 1998 & 0 & $2009-1 C$ \\
\hline Yollege of New Jersey & & & $\sqrt{ }$ & & & 1995 & 3 & 2012-13 \\
\hline Jew Mexico State University & & & & $\sqrt{ }$ & & 2007 & 6 & 2012-13 \\
\hline $\begin{array}{l}\text { State University of New York } \\
\text { at Stony Brook }\end{array}$ & & & $\sqrt{ }$ & & & 1965 & 4 & 2011-12 \\
\hline $\begin{array}{l}\text { Wity University of New York, } \\
\text { 'ollege of Staten Island } \\
\end{array}$ & & & $\sqrt{ }$ & & & 1985 & 0 & 2008-0 \\
\hline The University of Oklahoma & & & & $\sqrt{ }$ & & 1953 & 10 & 2011-12 \\
\hline $\begin{array}{l}\text { ranklin W. Olin College of } \\
\text { ingineering }\end{array}$ & $\sqrt{ }$ & & & & & 2007 & 2 & 2012-13 \\
\hline )livet Nazarene University & $\sqrt{ }$ & & & & & 2000 & 0 & $2011-12$ \\
\hline
\end{tabular}

Proceedings of the 2008 ASEE Gulf-Southwest Annual Conference

The University of New Mexico - Albuquerque

Copyright $(0) 2008$, American society for Engineering Education 
TABLE 2 (Continued). Multidisciplinary and Other Engineering Programs

\begin{tabular}{|c|c|c|c|c|c|c|c|c|}
\hline \multirow[b]{2}{*}{ College / University } & \multicolumn{5}{|c|}{ Multidisciplinary Engineering Areas } & \multicolumn{3}{|c|}{ Other Information } \\
\hline & 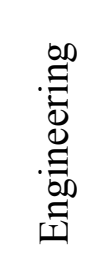 & 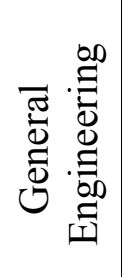 & 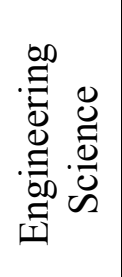 & 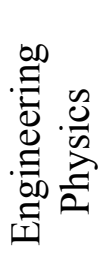 & 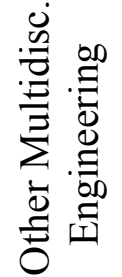 & 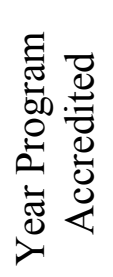 & 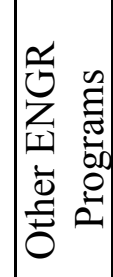 & 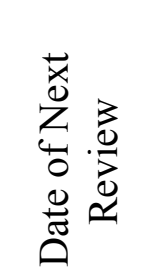 \\
\hline )ral Roberts University & $\sqrt{ }$ & & & & & 1994 & 0 & $2011-12$ \\
\hline University of the Pacific & & & & $\sqrt{ }$ & & 1986 & 5 & 2012-13 \\
\hline $\begin{array}{l}\text { 'ennsylvania State University } \\
\text { University Park, PA) }\end{array}$ & & & $\sqrt{ }$ & & & 1959 & 17 & $2008-05$ \\
\hline University of Pittsburgh & & & & $\sqrt{ }$ & & 1994 & 8 & 2011-12 \\
\hline 'rinceton University & & & & $\sqrt{ }$ & & 1972 & 5 & $2007-0 \varepsilon$ \\
\hline $\begin{array}{l}\text { Rensselaer Polytechnic } \\
\text { Institute }\end{array}$ & & & & $\sqrt{ }$ & & 1993 & 12 & 2007-08 \\
\hline :obert Morris University & $\sqrt{ }$ & & & & & 2004 & 1 & $2009-1 C$ \\
\hline 'oger Williams University & $\sqrt{ }$ & & & & & 2000 & 0 & $2011-12$ \\
\hline mith College & & & $\sqrt{ }$ & & & 2005 & 0 & 2010-11 \\
\hline $\begin{array}{l}\text { outheast Missouri State } \\
\text { Iniversity }\end{array}$ & & & & $\sqrt{ }$ & & 2001 & 0 & 2012-13 \\
\hline Iniversity of Southern Indian & $\sqrt{ }$ & & & & & 2007 & 0 & 2012-13 \\
\hline outhern Utah University & & & & & $\sqrt{ }$ & 2005 & 0 & $2010-11$ \\
\hline $\begin{array}{l}\text { tevens Institute of } \\
\text { echnology }\end{array}$ & $\sqrt{ }$ & & & & & 1936 & 7 & $2009-1 \mathrm{C}$ \\
\hline warthmore College & $\sqrt{ }$ & & & & & 1936 & 0 & 2010-11 \\
\hline arleton State University & & & & $\sqrt{ }$ & & 2006 & 0 & 2011-12 \\
\hline $\begin{array}{l}\text { Iniversity of Tennessee at } \\
\text { thattanooga }\end{array}$ & $\sqrt{ }$ & & & & & 1977 & 2 & $2009-1 C$ \\
\hline $\begin{array}{l}\text { Jniversity of Tennessee at } \\
\text { Tartin }\end{array}$ & $\sqrt{ }$ & & & & & 1999 & 0 & 2010-11 \\
\hline exas Christian University & $\sqrt{ }$ & & & & & 1997 & 0 & $2008-0 s$ \\
\hline 'exas Tech University & & & & $\sqrt{ }$ & & 1965 & 8 & 2011-12 \\
\hline rinity College & $\sqrt{ }$ & & & & & 1994 & 0 & $2011-12$ \\
\hline rinity University & & & $\sqrt{ }$ & & & 1969 & 0 & 2011-12 \\
\hline he University of Tulsa & & & & $\sqrt{ }$ & & 1971 & 4 & 2012-13 \\
\hline
\end{tabular}


TABLE 2 (Continued). Multidisciplinary and Other Engineering Programs

\begin{tabular}{|c|c|c|c|c|c|c|c|c|}
\hline & \multicolumn{5}{|c|}{ Multidisciplinary Engineering Areas } & \multicolumn{3}{|c|}{ Other Information } \\
\hline College / University & 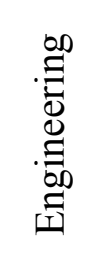 & 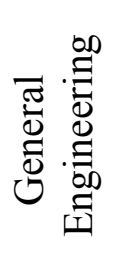 & 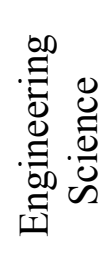 & 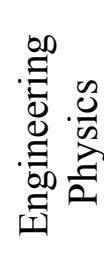 & 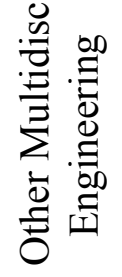 & 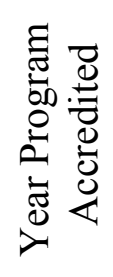 & 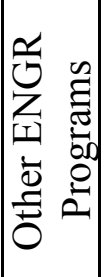 & 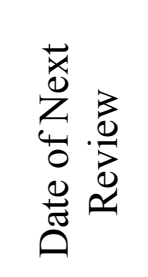 \\
\hline Inion University & $\sqrt{ }$ & & & & & 2006 & 0 & $2011-12$ \\
\hline Valla Walla College & $\sqrt{ }$ & & & & & 1971 & 0 & $2007-0 \varepsilon$ \\
\hline $\begin{array}{l}\text { Iniversity of Wisconsin- } \\
\text { 'latteville }\end{array}$ & & & & $\sqrt{ }$ & & 2001 & 6 & 2012-13 \\
\hline Vright State University & & & & $\sqrt{ }$ & & 1988 & 6 & 2011-12 \\
\hline
\end{tabular}

$\begin{array}{lllllll}\text { Total Schools with Program } & 34 & 3 & 11 & 19 & 5\end{array}$

TABLE 3. Multidisciplinary Engineering Program Accreditation Schedule (ABET Website)

\begin{tabular}{|c|c|c|c|c|c|c|}
\hline $\begin{array}{c}\text { Date of } \\
\text { Next } \\
\text { Review }\end{array}$ & $\begin{array}{c}\text { Number of } \\
\text { Universities }\end{array}$ & Engineering & $\begin{array}{c}\text { General } \\
\text { Engineering }\end{array}$ & $\begin{array}{c}\text { Engineering } \\
\text { Science }\end{array}$ & $\begin{array}{c}\text { Engineering } \\
\text { Physics }\end{array}$ & $\begin{array}{c}\text { Other } \\
\text { Multidisc. } \\
\text { Eng. }\end{array}$ \\
\hline $2007-08$ & 9 & 4 & 1 & 1 & 3 & 1 \\
\hline $2008-09$ & 5 & 3 & 0 & 2 & 0 & 0 \\
\hline $2009-10$ & 9 & 6 & 0 & 1 & 2 & 0 \\
\hline $2010-11$ & 10 & 6 & 2 & 1 & 0 & 1 \\
\hline $2011-12$ & 20 & 10 & 0 & 4 & 5 & 1 \\
\hline $2012-13$ & 16 & 5 & 0 & 2 & 9 & 2 \\
\hline Total & $\mathbf{6 9}$ & $\mathbf{3 4}$ & $\mathbf{3}$ & $\mathbf{1 1}$ & $\mathbf{1 9}$ & $\mathbf{5}$ \\
\hline
\end{tabular}

TABLE 4. Dates of Next General Review for Continuing Accreditation

\section{Date of Next Review: 2007-08}

1. Calvin College

2. Colorado State University

3. Embry-Riddle Aeronautical University - Daytona Beach

4. Massachusetts Institute of Technology (2)

5. Mercer University

6. Princeton University

7. Rensselaer Polytechnic Institute

8. University of Illinois at Urbana-Champaign

9. Walla Walla College 
TABLE 4 (Continued). Dates of Next General Review for Continuing Accreditation

Date of Next Review: 2008-09

1. City University of New York, College of State Island

2. John Brown University

3. LeTourneau University

4. Pennsylvania State University (University Park, PA)

5. Texas Christian University

Date of Next Review: 2009-10

1. Dartmouth College

2. Fort Lewis College

3. Harvard University (Cambridge, MA)

4. Harvey Mudd College

5. McNeese State University

6. Murray State University

7. Robert Morris University

8. Stevens Institute of Technology

9. University of Tennessee at Chattanooga

\section{Date of Next Review: 2010-11}

1. Arkansas State University

2. George Fox University

3. Grand Valley State University

4. Michigan Technological University

5. Montana Tech of the University of Montana

6. Smith College

7. Southern Utah University

8. Swarthmore College

9. University of Denver

10. University of Tennessee at Martin

\section{Date of Next Review: 2011-12}

1. California Institute of Technology

2. Dordt College

3. Hofstra University

4. Hope College

5. Idaho State University

6. Loyola College in Maryland

7. Messiah College

8. Olivet Nazarene University

9. Oral Roberts University

10. Roger Williams University

11. State University of New York at Stony Brook

12. Tarleton State University

13. Texas Tech University 
TABLE 4 (Continued). Dates of Next General Review for Continuing Accreditation

14. The University of Oklahoma (2)

15. Trinity College

16. Trinity University

17. Union University

18. University of Maryland College Park

19. University of Pittsburgh

20. Wright State University

\section{Date of Next Review: 2012-13}

1. Baylor University

2. Carnegie Mellon University

3. Case Western Reserve University (2)

4. College of New Jersey

5. New Mexico State University

6. Franklin W. Olin College of Engineering

7. Colorado School of Mines (2)

8. Geneva College

9. Southeast Missouri State University

10. University of Southern Indiana

11. The University of Kansas

12. The University of Tulsa

13. University of Florida

14. University of Maine

15. University of the Pacific

16. University of Wisconsin-Platteville

\section{References}

1. James Farison and Byron Newberry, "The current status and uses of the general (undesignated) engineering program with a case study," ASEE Annual Conference and Exhibition Proceedings (CD-ROM, \#1765, 9 pages), Nashville, Tennessee, June 22-25, 2003.

2. Byron Newberry and James Farison, "A look at the past and present of general engineering and engineering science programs," Journal of Engineering Education, 93(3):217-226, July 2003.

3. Jim Farison and Byron Newberry, "Curricular and student characteristics of accredited engineering/general engineering programs," ASEE Annual Conference and Exhibition Proceedings, Session 1471 (CD-ROM, 19 pages), Salt Lake City, Utah, June 13-25, 2004.

4. http://www.abet.org/accrediteac.asp

5. Jim Farison, "ASEE initiative in multidisciplinary engineering education programs," ASEE Gulf Southwest Section Conference Proceedings (CD-ROM, 8 pages), Lubbock, Texas, March 10-12, 2004.

6. Jim Farison, "ASEE MECC: The great story of a successful member initiative," ASEE Annual Conference and Exhibition Proceedings (CD-ROM. 9 pages), Portland, Oregon, June 12-15, 2005.

7. John A. Weese, Edwin C. Jones and Sherra E. Kerns, "ASEE \& ABET interactions and collaborations," ASEE Annual Conference and Exhibition Proceedings, Portland, Oregon, June 12-15, 2005.

8. Sherra E. Kerns, "A lead society - ASEE has taken on a major new role in selecting and training ABET accreditation evaluators," PRISM, vol. 24, no. 9, Summer 2005 (asee today), President's Letter), p. 53.

9. Jim Farison, "ASEE's new role in the ABET program accreditation process," ASEE Gulf-Southwest Annual Conference Proceedings (12 pages), Baton Rouge, Louisiana, March 15-17, 2006.

10. http://www.asee.org/about/committees.cfm\#Accreditation

Proceedings of the 2008 ASEE Gulf-Southwest Annual Conference

The University of New Mexico - Albuquerque

Copyright $(0) 2008$, American society for Engineering Education 
11. http://www.asee.org/about/Accreditation-Committee.cfm

12. Jim Farison and Carmen LiShen, "A Look at the Programs in Multidisciplinary Engineering Areas for which ASEE Is Now the Lead Society for ABET Accreditation Review," ASEE Annual Conference and Exhibition Proceedings (18 pages), Chicago, Illinois, June 18-21, 2006.

13. Jim Farison and Carmen LiShen, "ASEE's New Role as the Lead Society for ASEE Accreditation Review of Multidisciplinary Engineering Programs: An Update and a Look Ahead," ASEE Annual Conference and Exhibition Proceedings (14 pages), Honolulu, Hawaii, June 24-27, 2007.

\section{JAMES B. FARISON}

Dr. Farison is a professor in Baylor's ECE department, and also coordinates Baylor's interdepartmental, multidisciplinary Engineering major. He holds M.S./Ph.D. in EE from Stanford U., and served over 34 years at the U. Toledo, $\mathrm{OH}$, including 10 years as Engrg. Dean. He is an ASEE Fellow, ASEE Accreditation Activities Committee member, ASEE Multidisciplinary Engineering Division past chair, Baylor's ASEE campus rep, and PE in OH, TX.

\section{ZHUOCHENG YANG}

Mr. Yang received his Bachelor of Science degree in Electrical Engineering from Donghua University, Shanghai, China, in 2006, and is currently a graduate student in the Department of Electrical and Computer Engineering at Baylor University. He has previously worked in applications of image processing, and expects to conduct his master thesis research in that area. 